\title{
The study of human values in understanding and managing social-ecological systems
}

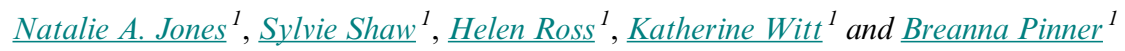

\begin{abstract}
The study of cognition can provide key insights into the social dimension of coupled social-ecological systems. Values are a fundamental aspect of cognition, which have largely been neglected within the social-ecological systems literature. Values represent the deeply held, emotional aspects of people's cognition and can complement the use of other cognitive constructs, such as knowledge and mental models, which have so far been better represented in this area of study. We provide a review of the different conceptualizations of values that are relevant to the study of human-environment interactions: held, assigned, and relational values. We discuss the important contribution values research can make toward understanding how social-ecological systems function and to improving the management of these systems in a practical sense. In recognizing that values are often poorly defined within the social-ecological systems literature, as in other fields, we aim to guide researchers and practitioners in ensuring clarity when using the term in their research. This can support constructive dialogue and collaboration among researchers who engage in values research to build knowledge of the role and function of values, and hence cognition more broadly, within a social-ecological systems context.
\end{abstract}

Key Words: cognition; human-nature relationships; values

\section{INTRODUCTION}

The study of cognition within social-ecological systems (SES) is an important yet relatively neglected area of research, which can be used to enhance understanding of how these systems function (Hukkinen 2012) and can be drawn upon to improve environmental management initiatives (Beratan 2007, Jochum et al. 2014). In a SES, human systems and ecological systems are inextricably linked: people rely upon resources provided by ecosystems, and ecosystems are influenced by people's decisions and behaviors (Chapin et al. 2009a). Through participating in a SES people, both individually and collectively, develop multifaceted relationships with the environment that strongly influence their views as to how natural resources should be used and managed. Cognitive dimensions, the many ways in which people think about their environments, and the ways their thinking is influenced by those environments, deserve more attention in efforts to understand how social and ecological systems are coupled.

A number of constructs have been used to study the cognitive basis of how people relate to ecosystems, including knowledge (Turner and Berkes 2006), schema (Beratan 2007), mental models (Jones et al. 2011, Mathevet et al. 2011, Lynam et al. 2012), and attitudes (Larson et al. 2013a). We focus on values as the most stable form of human cognition (Ives and Kendal 2014). Reser and Bentrupperbäumer (2005:129) explain values as more "central," "deeply considered," and "strongly held" than attitudes. Values underpin decisions and behavior (Satterfield 2001), thus studying values can provide insight into people's differing viewpoints about how environment resources should be used, managed (Jackson et al. 2008), and experienced. Although a study of mental models aims to elicit people's understanding of how environmental systems function, a study of values can tap into the moral and less tangible aspects of people's cognition. Values can therefore complement the use of other forms of cognition to enhance understanding of the deeply felt and emotional basis of people's interactions with natural systems, can further understanding of how SES function, and can strengthen their management.

Numerous authors have identified values as an important and influential element within SESs, by linking the notion of values, albeit loosely, to key themes within the SES field, including social memory (Olsson et al. 2004), transformation (Walker et al. 2006), governance (Olsson et al. 2006), adaptation (Folke et al. 2010), and resilience-based management (Chapin et al. 2009a). However, use of the term "values" within the SES literature, and the environmental literature more broadly, is ambiguous and often lacks a clear conceptualization (Reser and Bentrupperbäumer 2005). In particular, social scientists think of values as being generated by humans, whereas in ecological discourse it is common to see species and ecosystems described as having inherent values, e.g., world heritage values. This limits the extent to which researchers can build upon the work of others and constrains the depth to which the notion of values within a SES can be explored.

Reser and Bentrupperbäumer (2005) identified several implications of conflicting meanings and usages of "environmental values" within the environmental management literature, including the inhibition of collaborative research in a cross-disciplinary context. As the study of cognition gains momentum within the SES field, issues of inconsistency become increasingly pertinent. In particular, they highlight the benefit of establishing a cross-disciplinary understanding of the meaning and usage of values in a given field to avoid misunderstandings and miscommunication: "effective communication," "collaboration," and "good science" are all dependent upon core constructs being clearly defined (Reser and Bentrupperbäumer 2005:128).

Reser and Bentrupperbäumer (2005:141) take a social science perspective to describe environmental values, as "individual and shared community or societal beliefs about the significance, 
importance, and well-being of the natural environment, and how the natural world should be viewed and treated by humans." This definition is also suitable for conceptualizing human values within a SES context. From this perspective, values do not exist within the environment; instead the environment and its attributes have value for people (Reser and Bentrupperbäumer 2005). This differentiation is important to ensure clarity of debate as the understanding of SES evolves and that appropriate methodologies and metrics are applied to the study of human values.

From a psychological standpoint, values are deeply held, cognitive elements that deal with preferred states. Schwartz (1994:20) builds upon the work of Rokeach (1973) to define a value as a "belief pertaining to desirable end states or modes of conduct that transcends specific situations, guides selection or evaluation of behaviour, people, and events, and is ordered by importance relative to other values to form a system of value priorities." Values are understood to form in childhood, taking shape through socialization processes and through interacting with the world, and remain relatively stable throughout adult life (Stern and Dietz 1994, Vaske et al. 2001). As stable moral guidelines, values are "more fundamental, and salient and influential, normatively, emotionally and motivationally than preferences or attitudes" (Reser and Bentrupperbäumer 2005:141).

Values interact with other forms of cognition, as outlined within the cognitive hierarchy model of human behavior, a framework used to explain how a person's view of an environment is structured (Vaske and Donnelly 1999). A number of theorists support the contention that values provide a foundation for attitudes and beliefs, which in turn influence behavior or intention (Kluckhohn 1951, Fulton et al. 1996, Vaske and Donnelly 1999), although the links may be weak. This hierarchy is described as an inverted pyramid consisting of values, value orientations (i.e., clusters of basic values), attitudes and norms, behavior intentions, and behaviors (Fulton et al. 1996), with each element layered upon others (Fig. 1). Values at the bottom of the pyramid are described as cognitive elements, which transcend situations, are slow to change, and are few in number, whereas behaviors are situation specific, faster to change, and numerous.

Whereas in psychology values are studied at both the individual and collective levels, including the relationship between them (Schwartz 2010), other disciplines including geography (Ioris 2012) and anthropology (Strang 2005) contribute with respect to collective values. For example, cultural values within anthropology refer to the values that are shared among a group of people and may differentiate one group from another (Robbins 2012).

Conceptualization of values as a human construct only goes part of the way in clarifying the nature and role of human values within SES. To advance this field, researchers from the many disciplines contributing to the study of SES should make further distinctions in their usage of the term values and in the breadth of scope they apply in studying values. We provide a review of the different ways in which the notion of values is used in the field of environmental and natural resource management (NRM), drawing particularly upon the individual dimensions of values, influenced by the psychology literature. This is followed by an overview of how studying values can enhance our understanding of SES dynamics and can be applied to strengthen the management of a SES.
Fig. 1. Cognitive hierarchy model of human behavior, adapted from Fulton et al. (1996).

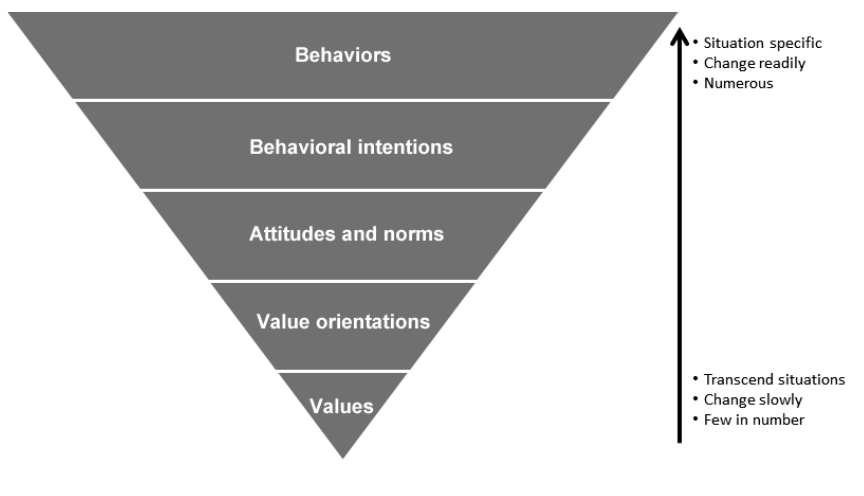

\section{VALUES AS UNDERSTOOD IN THE FIELDS OF ENVIRONMENTAL AND NATURAL RESOURCE MANAGEMENT}

To structure our review, we have identified two dimensions along which the study of values differ: (1) the degree of abstractness; and (2) the breadth of scope scholars take in studying values, ranging from single to multiple values.

\section{Abstract to applied values}

A review of the environmental management and NRM literature reveals a distinction between studies that focus upon broad, generic environmental values, known as held values; those that are applied in a specific context, known as assigned values; and the realm of values that reflect lived experiences known as felt or relational values (Schroeder 2013).

Held values represent ideals of what is desirable (Bengston 1994), how things ought to be, and how one should interact with the world. They are generic, conceptual, and abstract (Brown 1984, McIntyre et al. 2008). For Brown (1984:232), held values can take the form of desirable "modes of behaviour," e.g., loyalty, "end states," e.g., freedom, or "qualities," e.g., beauty, and provide the basis for preference judgements to be made. Lockwood (1999:382) explains held values as "principles or ideas that are important to people," which can determine the more locally specific assigned values.

A cluster of held values is referred to as a value orientation and is usually applied to a particular topic, such as wildlife conservation (Lockwood 1999, Vaske and Donnelly 1999). A number of studies have been conducted to identify and map different types of environmental value orientations (Rolston 1988, Axelrod 1994, Bengston 1994, Steel et al. 1994, Stern and Dietz 1994, Stern et al. 1998, Manning et al. 1999, Vaske et al. 2001, Vugteveen et al. 2010). These studies build upon the ideas of Schwartz (1992), whose work has been highly influential in values research in psychology (e.g., Steg et al. 2005). Schwartz identifies 10 universal value types: self-direction, stimulation, hedonism, achievement, power, security, conformity, tradition, benevolence, and universalism, which are organized into a values system. Such a system structures and prioritizes values to meet 
universally important biological and social needs (Rokeach 1973, Schwartz 1996). The dynamic relationships and trade-offs that take place between the different universal value types cluster together to form a value orientation and guide behavior (Fulton et al. 1996, Schwartz 1996). This concept is used to understand differences in how people prioritize values and can be useful in understanding how a pattern of value-based preferences can become a culture or ethic. Some authors share the view that value orientations toward natural resources can be mapped along a continuum with an anthropocentric (human-centred) orientation at one end and a biocentric (nature-centred) orientation at the other (Steel et al. 1994, Fulton et al. 1996, Vaske and Donnelly 1999).

Assigned values are more familiar in the environmental management literature. They are shaped by held values. In a NRM context, assigned values are attached to certain places (Seymour et al. 2012), species, or other features of the natural world, as well as to certain objects, activities, or places (Lockwood 1999, Bryan et al. 2010), such as tropical rivers in northern Australia (Larson et al. 2013b). Brown (1984:236) defined this type of value as "the expressed relative importance or worth of an object to an individual or group in a given context." McIntyre et al. (2008:660) stated that assigned values are "focused on comparative judgements about the worth of an 'object' in a given context and are therefore quite specific and concrete." Seymour et al. (2010) argued that within a NRM context, assigned values are a better predictor of behavior than held values. They claim that assigned values are shaped not only by held values but are also influenced by a number of other factors, including socialization processes, knowledge and perception, contextual factors, and the characteristics of the resource valued.

Brown (1984) proposed a third realm of values, i.e., relational values, which explain the relationship between held and assigned values. Relational values are those arising from the relationship between a subject and an object and are associated with the act of preferring. They involve feelings. Brown posits a linear relationship between three realms of values, suggesting that held values (the conceptual realm) influence preference judgements (relational realm), which result in a behavioral expression of preference (object realm), i.e., assigned values. Schroeder (2013) builds upon Brown's work to further explore this relational realm. In doing so, he rejects Brown's linear conceptualization of the valuing process by placing greater emphasis on feeling and the implicit nature of values to propose felt values, as "the immediate, subjective feeling of importance, worth, or significance that something has for an individual" (Schroeder 2013:77). The immediate quality of these values renders them context specific. Schroeder asserted that felt values, existing at an implicit level of awareness, can shape and be shaped by both held and assigned values, which exist at the explicit level. Furthermore, he stated that within a person's immediate experience "felt value underlies and is more fundamental than either held values or assigned values" (Schroeder 2013:78). Barkley and Kruger (2012:93) acknowledged the implicit quality of Schroeder's felt values, describing them as a reflection of an "internal, personal understanding of lived experience." They draw attention to the interplay between emotion and memory, which is involved in making felt values explicit and externalizing them into held and assigned values.

\section{Unidimensional versus pluralist approaches}

Values within an environmental management and NRM context have been studied from both unidimensional and pluralist perspectives. A unidimensional perspective assumes that people's values can be measured using a single scale, such as an economic or utilitarian scale. Unidimensional valuation approaches have been criticized on the grounds that they do not take into account the variety of ways in which people value the environment. They provide only a partial view of people's environmental values (Bengston 1994, O'Neill et al. 2008) and fail to account for the moral and ethical aspects (Clark et al. 2000). Satterfield (2001:332) also asserted that such approaches do not allow participants to voice those more intangible values that are "deeply held, privately defended or not available to consciousness at a moment's notice." Limitations associated with using a purely economic approach to study how people value the environment are widely expressed in the literature (Bengston 1994, O'Brien 2003).

A pluralist, or multidimensional, perspective acknowledges that people hold diverse values and thus accepts that the environment is valued in multiple ways. A number of authors have identified typologies or classification systems to account for the variety of ways people value the natural world, including the geo-diversity of the planet (Gray 2004), landscapes (Stephenson 2008), wetlands and rivers (Seymour et al. 2011), forests (Manning et al. 1999, Brown and Reed 2000), as well as wildlife and nature (Kellert 1996, Trainor 2006).

Stephen Kellert's $(1996,2008)$ typology is particularly relevant to understanding SESs, in that it provides a holistic identification of people's multifaceted relationships with the environment. Kellert's typology builds upon the biophilia hypothesis (Kellert and Wilson 1993, Kellert 1997) that proposes that people have a "complex of weak biological tendencies to value nature" (Kellert 2008:324). This holds that people's values in relation to the environment are founded in human biological requirements and are shaped and mediated by individual and cultural learning and experience (Kellert 2008). According to the biophilia hypothesis, nature-based values have an adaptive function in a context of human dependence upon the natural world (Caston 2013), which Kellert (2008) argued provides benefits to peoples' mind, body and spirit.

Through numerous studies, Kellert developed a typology of 10 values that signify people's relationship to the natural world (Table 1). They are: aesthetic, dominionistic, ecologistic-scientific, humanistic, moralistic, naturalistic, negativistic, spiritual, symbolic, and utilitarian. In its recognition of multiple interdependencies between human well-being and ecological condition and function, Kellert's typology is particularly useful for understanding coupling in SESs.

\section{IMPLICATIONS FOR UNDERSTANDING AND MANAGING SOCIAL-ECOLOGICAL SYSTEMS}

The conceptual categories advocated above can assist those seeking to understand or manage SESs to focus more clearly on the coupled nature of the system. When talking of values, researchers and managers can first be explicit about whether they are focusing on the social or ecological part of the system. Following Reser and Bentrupperbäumer's (2005) call for terminological clarity, they can make clear whether they follow a 
Table 1. Kellert's nature-related values typology (Kellert 1996, 2012).

\begin{tabular}{ll}
\hline \hline Value & Definition \\
\hline Aesthetic & Appreciation of the physical appeal and beauty of nature \\
Dominionistic & Mastery, physical control, dominance of nature \\
Ecologistic-scientific & Appreciation of structure, function, and relationships in nature \\
Humanistic & Strong emotional attachment and "love" for aspects of nature \\
Moralistic & Ethical concern for nature \\
Naturalistic & Enjoyment of immersion in nature \\
Negativistic & Fear, aversion, alienation from nature \\
Spiritual & Feelings of transcendence; reverence for nature \\
Symbolic & Inspiration from nature in language and thought \\
Utilitarian & Benefits from the practical use and material exploitation of nature \\
\hline
\end{tabular}

social science or ecological understanding, i.e., whether they assume a value is a human phenomenon or is inherent in the species or ecosystem. In our terminology, the latter is an assigned value. With respect to each assigned value, it would be useful to establish why that species or ecosystem is deemed important to an individual, or group, and to identify the held or relational values associated with it. For instance, is an assigned value toward a species associated with a moralistic or an ecologistic-scientific held value (using Kellert's 1996 concepts), as rationale for protecting that species?

Fulton et al.'s (1996) cognitive hierarchy model of human behavior offers clarity about the relationships between different forms of cognition and behavior, and the opportunity to go beyond the more superficial (and fast variable) underpinnings of behavior, such as attitudes, into the deeper, more fundamental, and slower changing aspects of cognition. Social systems are coupled with ecological systems in complex ways, which are simultaneously cognitive and behavioral. System change is best addressed by considering all of the levels in the Fulton et al. model, rather than focusing on one level to the neglect of the others. Can there be stronger commitment to behavior change and can it be more enduring, if linked to a person's values? Can an appeal to value change support behavior change on the part of enough people to mobilize a system change? This model, however, refers generically to values, not their variants recognized in the later environmental management literature. The ability to discern held values, i.e., focused on general principles as to why humans relate to their ecosystems in particular ways, from assigned values, i.e., the application of those principles to particular ecosystems or species, and appreciate their linking and usually less explicit relational values, potentially expands understanding of a SES and offers new intervention points. People may hold values toward protecting the environment, and they may also assign these held values toward particular species or places, such as those identified as highly threatened or those that are deemed charismatic (Bottrill et al. 2008), or toward ecological assemblages, such as rainforests. A held-relationalassigned conceptualization of values suggests opportunity to work across what is valued, why, and by whom, and hence to intervene at more than one point in this dynamic array.

\section{The role of values in understanding system change}

There is potential for exploring the role of human values as a driver of change within SESs or as an influence on known drivers. We should also be interested in how values may alter, over time, in response to system changes. Further, given understanding of the relationships between levels in multilevel SESs, how are held values shared or how do they differ between individual and societal levels in particular contexts? How can value change at one level mobilize, or retard, change at other levels and across the entire system? Do values play roles in processes of change such as Rudel's (2011) explanation of "defensive" and "altruistic" environmentalism driving multilevel change? Similarly, how does the existence of competing held values at a societal level influence change within a system? Examples could be where leadership, driven by some individuals' values, mobilizes changes in people's and organizations' values at higher levels, or conversely where progressive value change across a society draws a critical mass of individuals into amending their held and assigned values. Is diversity in values at a societal level a reservoir of potential for constructive change throughout the system? How do values relate to other variables such as social learning, in driving change? Further, how do values relate to significant changes in behavior, which collectively may mobilize system change?

Values research can also play a role in the creation of narratives that promote change within a SES: narratives that are not only shaped by the language of economics, demography, and institutions, but also guided by notions of social well-being (Armitage et al. 2012). Held values provide principles for such narratives, whereas assigned and relational values can draw wellbeing into narratives for change within specific contexts.

Further, SES literature seeks to understand the effects of different variables operating at different temporal scales: fast and slow variables (Walker et al. 2012). There is currently greater understanding of the nature and dynamics of ecological variables than of social variables (Kofinas and Chapin 2009, Armitage et al. 2012), including values. Armitage et al. (2012) assumed that variables that involve human agency are transient and open to change, making them difficult to identify and control. This observation is not consistent with theory on values, which are deemed to be very stable. Held values are more stable and slower to change in comparison to assigned values, whereas relational values are experience based and highly context dependant. Thus held values may provide a slow variable, that helps to anchor a SES (cf. Rotarangi and Stephenson 2014 on pivots of cultural resilience).

\section{Incorporating values in management of social-ecological systems (SES)}

Understanding how people relate to natural resources is recognized as a key component of effective management for those 
practitioners working from a SES perspective: "resource management is people management" (Berkes and Folke 1998:2). A study of human values can guide managers in the design of management strategies that align with people's values (Chapin et al. 2009b). Chapin, et al.'s (2009a) resilience-based NRM approach takes a step further to advocate that management efforts should not only respond to human values but should also shape them. The practicalities of how managers can do this, however, requires theoretical guidance on how values are to be considered in a SES context and applied knowledge of what those values are.

A study of held values can shed light upon people's "enduring beliefs that a specific mode of conduct is personally or socially preferable to an opposite or converse mode of conduct" (Rokeach 1968:160), for instance the pursuit of self-interest versus concern for the welfare of the environment or others. A study of assigned values, meanwhile, can reveal how people think about specific aspects of the environment, including the importance they attach to certain places, species, and ecological functions. A study of relational values can provide a detailed view of the mental and physical benefits people derive, or seek to derive, from interactions with the environment or certain species.

\section{Enriching bottom-up (participatory) decision making}

Using information on values to guide the development of management interventions aligns well with the current trend of using bottom-up participatory processes in decision making (Kofinas and Chapin 2009, Charles 2012). Benefits include greater public support, which can increase the likelihood of successful management outcomes (Larson et al. 2013a) and ultimately contribute to a well-functioning SES (Raymond et al. 2009), as well as improvements in adaptation interventions (Adger et al. 2009). For instance, management plans and strategies rely heavily upon biophysical science lines of inquiry and so are less likely to incorporate a social focus. A mounting theoretical literature supports a prominent role for participatory processes, which engage a diversity of people in the design of management plans and policies, and hence offer potential for solutions that are more consistent with people's values. This is particularly important for researchers advocating a postnormal scientific posture (Swedeen 2006).

Bottom-up processes, however, are challenged by the social realities of competing interests about the use and management of many environments. Clearly people, individually or collectively, do not relate to ecosystems according to a single value, such as use, or economic value. Although Davenport and Anderson (2005) assume that differences in values can prove difficult to reconcile and can constrain management plans and objectives, research revealing divergent values can also enhance management by exposing the wider dimensions of an issue and so prompt stronger problem solving. Values studies can thus be used to inform management decisions that involve trade-offs between obtaining certain environmental or social benefits at the expense of other benefits. Kellert's (1996) framework of values, or others such as Seymour et al.'s (2012), offer bases for exploring the range of held and assigned values a set of stakeholders may hold toward an area, such as a protected area. Discussion of these values and how to reconcile them in protection and access decisions, such as a zoning plan, could enrich current participatory planning approaches.
The conflict resolution literature (Forester 1999) and public policy literature (Thacher and Rein 2004) recognize value conflicts as occurring between, and also within, individuals and organizations. Where these bodies of literature tend to focus on very few, typically conflicting, values, typologies such as Kellert's demonstrate that multiple held or relational values can be assigned to a particular ecosystem or species. This can offer the challenges in policy and management of moderating across multiple interests, but also some opportunities. The more overt competing interests within a coupled SES may be muted within a broader perspective and, as the conflict resolution literature advocates, shared, higher-order values can be identified, which people can agree to give precedence over those that are in direct conflict.

Navigation of differences in values can thus play an important role in averting, or solving, conflicts. Study of held and assigned values in combination can provide a more nuanced analysis of environmental tensions and conflicts. It may demonstrate that different people may hold the same values, yet assign them to different objects, such as different species or places. Conversely, people may assign high value to the same place or species, but be in conflict over how that place or species should be managed owing to contrasting held values. A study of relational values, meanwhile, can be used to explore the subjective, implicit level of feeling: what feelings are conjured up when interacting with certain species or experiencing specific places. Relational values are useful for ascertaining an individual's gut feeling in a decisionmaking context (Schroeder 2013). As Schroeder (1996:19) points out, values are tied to emotions: "Any time we are dealing with people's values, we are faced with emotion; and whenever we are confronted with strong emotions, we can be sure that something of value is at stake."

\section{Building acceptance for top-down decisions}

Public support for management interventions is a key concern for policy decision makers and those responsible for implementing activities (McDonald et al. 2013). Values research can enhance the degree to which scientifically driven management strategies are tailored, or promoted, to the local social context. This may overcome one of the key criticisms of top-down management approaches, that they are "insensitive and unresponsive to local conditions, human livelihoods, and community concerns" (Kofinas 2009:79). Study of values can equally be used to identify actual or potential misalignment between planned top-down management interventions designed to maintain a desirable system trajectory and stakeholders' values, which may lead to rejection of or noncompliance with those management plans.

Controversial management strategies, particularly those that are politically driven or poorly executed with little consideration for the local context, can lead to compliance problems, poor trust relations, and heightened conflict (Kofinas 2009). An exploration of values can shed light on the ways individuals might respond to management initiatives as a person draws upon their values to evaluate management goals and management actions (Bengston et al. 2004). By mapping the diversity of values associated with a SES, managers can assess how their management plans and strategies might impinge on individual and community values. In situations in which misalignment is observed, managers can design communication material that acknowledges and addresses 
this divergence. This is important as management efforts can be bolstered by community and social support (Biggs et al. 2010).

\section{Further research}

Research can also be directed toward understanding how values relate to the other cognitive structures and processes that have been studied in relation to the management of SESs, i.e., memory (Beratan 2007), social memory (Barthel et al. 2010, DiGiano and Racelis 2012), schema (Beratan 2007), and mental models (Jones et al. 2011, 2014, Mathevet et al. 2011, Lynam et al. 2012). For example, tentative links have already been made between values and social memory. Olsson et al. (2004), drawing upon the work of McIntosh (2000), explained social memory as a realm of shared experiences of change, which are entrenched in underlying values and are reflected in community decisions and strategies for dealing with further change. From their perspective, social memory, and therefore values, play an important role in the adaptive capacity of people in response to environmental change. These ideas present a wide scope for enhancing knowledge of the cognitive aspect of adaptive capacity, a key concept in SES functioning. What role do held, assigned, and relational values play in helping people to adapt to environmental change? Are values a strong driver in the desire to adapt and in adaptation choices? To what extent do some people's values constrain adaption, for example in adapting to climate change?

\section{CONCLUSIONS}

The study of values deserves a stronger place within the crossdisciplinary field of SES research, to further our growing understanding of the cognitive dimensions in the coupling of social and ecological systems. Although values are deemed the most fundamental aspect of cognition (Fulton et al. 1996), they have largely been neglected within the SES literature. As the cognitive hierarchy pyramid illustrates, values underpin an understanding of other forms of thinking and behavior that so far have received greater attention. As a slow changing form of cognition, the inclusion of values should also be of particular interest to SES theorists interested in system change through interactions among fast and slow variables (Scheffer et al. 2015). However, values research has been confounded by ambiguity in conceptualizations and uses of the term, particularly in environmental fields (Reser and Bentrupperbäumer 2005). This review dispels some of this ambiguity by providing a synthesis of values theories from the fields of psychology and environmental management and their potential application to SES theory and research.

Although values are held by people, they may be assigned to attributes of the environment, hence the common presumption that species or ecosystems have value independent of any beholder. Relational values express relationships between a person and environmental attributes, so are particularly worthy of consideration in coupled SESs. Pluralist perspectives recognize that people hold diverse sets of values, collectively and even individually, and there are several classifications derived from empirical studies (Kellert 1996, Brown and Reed 2000, Ananda and Herath 2003, McIntyre et al. 2008).

Theoretical research on values can improve our understanding of the contribution of cognitive dimensions within the coupled nature of SESs. A clearly conceptualized notion of values can be integrated with other SES concepts to enhance understanding of human-environment interactions. Applied values research can be used to guide managers in designing strategies that are in accordance with the key principles defined in SES literature, such as supporting pluralism, managing trade-off decisions, and shaping social goals and values to promote stewardship. When there is conflict between individuals or social groups with different sets of values, or different prioritizations of values, exploration and acknowledgement of these values can provide a basis for communication, stakeholder participation strategies, and design of more acceptable ways forward. It can assist with transparency and justification in management decisions in which prioritization among competing values is necessary. When decisions based on values compromise ecological function, as defined by biophysical studies, values research can provide an inclusive narrative for negotiating acceptable outcomes.

Given the multitude of possible conceptualizations of values identified, it is important for researchers to specify the theoretical basis of their use of the term values. Greater clarity will enable researchers to engage in constructive dialogue around the nature and functions of values within SES.

\section{Responses to this article can be read online at: http://www.ecologyandsociety.org/issues/responses. $\mathrm{php} / 7977$}

\section{Acknowledgments:}

This research is supported by ARC Linkage Grant LP100200475, conducted in association with the Queensland Government, Healthy Waterways, SEQ Catchments, and Aboriginal Traditional Custodians of the South East Queensland region. We also thank anonymous reviewers for comments that strengthened the work.

\section{LITERATURE CITED}

Adger, W. N., S. Dessai, M. Goulden, M. Hulme, I. Lorenzoni, D. R. Nelson, L. O. Naess, J. Wolf, and A. Wreford. 2009. Are there social limits to adaptation to climate change? Climatic Change 93:335-354. http://dx.doi.org/10.1007/s10584-008-9520Z

Ananda, J., and G. Herath. 2003. Incorporating stakeholder values into regional forest planning: a value function approach. Ecological Economics 45:75-90. http://dx.doi.org/10.1016/ S0921-8009(03)00004-1

Armitage, D., C. Béné, A. T. Charles, D. Johnson, and E. H. Allison. 2012. The interplay of well-being and resilience in applying a social-ecological perspective. Ecology and Society 17 (4):15. http://dx.doi.org/10.5751/es-04940-170415

Axelrod, L. 1994. Balancing personal needs with environmental preservation: identifying the values that guide decisions in ecological dilemmas. Journal of Social Issues 50:85-104. http://dx. doi.org/10.1111/j.1540-4560.1994.tb02421.x

Barkley, J. R., and L. E. Kruger. 2012. Place meanings as lived experience. Pages 89-98 in W. P. Stewart, D. R. Williams, and L. E. Kruger, editors. Place-based conservation: perspectives from the 
social sciences $>$ Springer, Dordrecht, Germany. http://dx.doi. org/10.1007/978-94-007-5802-5_7

Barthel, S., C. Folke, and J. Colding. 2010. Social-ecological memory in urban gardens - retaining the capacity for management of ecosystem services. Global Environmental Change 20:255-265. http://dx.doi.org/10.1016/j.gloenvcha.2010.01.001

Bengston, D. N. 1994. Changing forest values and ecosystem management. Society and Natural Resources 7:515-533. http://dx. doi.org/10.1080/08941929409380885

Bengston, D. N., T. J. Webb, and D. P. Fan. 2004. Shifting forest value orientations in the United States, 1980-2001: a computer content analysis. Environmental Ethics 13:373-392.

Beratan, K. K. 2007. A cognition-based view of decision processes in complex social-ecological systems. Ecology and Society 12 (1):27. [online] URL: http://www.ecologyandsociety.org/vol12/ iss $1 / \operatorname{art} 271$

Berkes, F., and C. Folke. 1998. Linking social and ecological systems for resilience and sustainability. Pages 1-25 in F. Berkes and C. Folke, editors. Linking social and ecological systems: management practices and social mechanisms for building resilience. Cambridge University Press, Cambridge, UK.

Biggs, R., F. R. Westley, and S. R. Carpenter. 2010. Navigating the back loop: fostering social innovation and transformation in ecosystem management. Ecology and Society 15(2):9. [online] URL: http://www.ecologyandsociety.org/vol15/iss2/art9/

Bottrill, M. C., L. N. Joseph, J. Carwardine, M. Bode, C. Cook, E. T. Game, H. Grantham, S. Kark, S. Linke, E. McDonaldMadden, R. L. Pressey, S. Walker, K. A. Wilson, and H. P. Possingham. 2008. Is conservation triage just smart decision making? Trends in Ecology and Evolution 23:649-654. http://dx. doi.org/10.1016/j.tree.2008.07.007

Brown, G. 2004. Mapping spatial attributes in survey research for natural resource management: methods and applications. Society and Natural Resources 18:17-39. http://dx.doi.org/10.1080/0894$\underline{1920590881853}$

Brown, G., and P. Reed. 2000. Validation of a forest values typology for use in national forest planning. Forest Science 46:240-247. [online] URL: http://www.landscapemap2.org/ publications/forestsciencepaper.pdf

Brown, T. C. 1984. The concept of value in resource allocation. Land economics 60:231-246. http://dx.doi.org/10.2307/3146184

Bryan, B. A., C. M. Raymond, N. D. Crossman, and D. H. McDonald. 2010. Targeting the management of ecosystem services based on social values: where, what, and how? Landscape and Urban Planning 97:111-122. http://dx.doi.org/10.1016/j. landurbplan.2010.05.002

Caston, D. 2013. Biocultural stewardship: a framework for engaging indigenous cultures. Minding Nature 6:22-32.

Chapin, F. S., III, C. Folke, and G. P. Kofinas. 2009b. A framework for understanding change. Pages 3-28 in F. S. Chapin, III, G. P. Kofinas, and C. Folke, editors. Principles of ecosystem stewardship: resilience-based natural resource management in a changing world. Springer, New York, New York, USA.
Chapin, F. S., III, G. P. Kofinas, C. Folke, S. Carpenter, P. Olsson, N. Abel, R. Biggs, R. L. Naylor, E. Pinkerton, D. M. Stafford Smith, W. Steffan, B. Walker, and O. R. Young. 2009a. Resiliencebased stewardship: strategies for navigating sustainable pathways in a changing world. Pages 319-338 in F. S. Chapin, III, G. P. Kofinas, and C. Folke, editors. Principles of ecosystem stewardship: resilience-based natural resource management in a changing world. Springer, New York, New York, USA.

Charles, A. 2012. People, oceans and scale: governance, livelihoods and climate change adaptation in marine socialecological systems. Current Opinions in Environmental Sustainability 4:351-357. http://dx.doi.org/10.1016/j.cosust.2012.05.011

Clark, J., J. Burgess, and C. M. Harrison. 2000. "I struggled with this money business": respondents' perspectives on contingent valuation. Ecological Economics 33:45-62. http://dx.doi. org/10.1016/S0921-8009(99)00118-4

Davenport, M. A., and D. H. Anderson. 2005. Getting from sense of place to place-based management: an interpretive investigation of place meanings and perceptions of landscape change. Society and Natural Resources 18:625-641. http://dx.doi. org/10.1080/08941920590959613

DiGiano, M. L., and A. E. Racelis. 2012. Robustness, adaptation and innovation: forest communities in the wake of Hurricane Dean. Applied Geography 33:151-158. http://dx.doi.org/10.1016/ j.apgeog.2011.10.004

Folke, C., S. R. Carpenter, B. Walker, M. Scheffer, T. Chapin, and R. Rockström. 2010. Resilience thinking: integrating resilience, adaptability and transformability. Ecology and Society 15(4):20. [online] URL: http://www.ecologyandsociety.org/vol15/iss4/ $\underline{\operatorname{art} 20 /}$

Forester, J. 1999. Dealing with deep value differences. Pages 463-494 in L. Susskind, S. McKearnan, and J. Thomas-Larmer, editors. The consensus building handbook. Sage, Thousand Oaks, California, USA. http://dx.doi.org/10.4135/9781452231389.n13

Fulton, D. C., M. J. Manfredo, and J. Lipscomb. 1996. Wildlife value orientations: a conceptual and measurement approach. Human Dimension of Wildlife 1:24-47. http://dx.doi. org/10.1080/10871209609359060

Gray, M. 2004. Geodiversity: valuing and conserving abiotic nature. John Wiley and Sons, West Sussex, UK.

Hukkinen, J. I. 2012. Fit in the body: matching embodied cognition with social-ecological systems. Ecology and Society 17 (4):30. http://dx.doi.org/10.5751/es-05241-170430

Ioris, A. A. R. 2012. The positioned construction of water values: pluralism, positionality and praxis. Environmental Values 21:143-162. http://dx.doi.org/10.3197/096327112X13303670567251

Ives, C. D., and D. Kendal. 2014. The role of social values in the management of ecological systems. Journal of Environmental Management 144:67-72. http://dx.doi.org/10.1016/j.jenvman.2014.05.013

Jackson, S., N. Stoeckl, A. Straton, and O. Stanley. 2008. The changing value of Australian tropical rivers. Geographical Research 46:275-290. http://dx.doi.org/10.1111/j.1745-5871.2008.00523. $\underline{\mathrm{x}}$ 
Jochum, K. A., A. A. Kliskey, K. J. Hundertmark, and L. Alessa. 2014. Integrating complexity in the management of humanwildlife encounters. Global Environmental Change 26:73-86. http://dx.doi.org/10.1016/j.gloenvcha.2014.03.011

Jones, N. A., H. Ross, T. Lynam, and P. Perez. 2014. Eliciting mental models: a comparison of interview procedures in the context of natural resource management. Ecology and Society 19 (1):13. http://dx.doi.org/10.5751/es-06248-190113

Jones, N. A., H. Ross, T. Lynam, P. Perez, and A. Leitch. 2011. Mental models: an interdisciplinary synthesis of theory and methods. Ecology and Society 16(1):46. [online] URL: http:// www.ecologyandsociety.org/vol16/iss1/art46/

Kellert, S. R. 1996. The value of life: biological diversity and human society. Island, Washington, D.C., USA.

Kellert, S. R. 1997. Kinship to mastery: biophilia in human evolution and development. Island, Washington, D.C., USA.

Kellert, S. R. 2008. A biocultural basis for an ethic toward the natural environment. Pages 321-332 in L. Rockwood, R. Stewart, and T. Dietz, editors. The foundations of environmental sustainability: the coevolution of science and policy. Oxford University Press, Oxford, UK. http://dx.doi.org/10.1093/acprof: oso/9780195309454.003.0021

Kellert, S. R., and E. O. Wilson. 1993. The biophilia hypothesis. Island, Washington, D.C., USA.

Kluckhohn, C. 1951. Values and value-orientations. Pages 388-433 in T. Parsons and E. A. Shils, editors. Toward a general theory of action. Harper and Row, New York, New York, USA.

Kofinas, G. P. 2009. Adaptive co-management in social-ecological governance. Pages 77-101 in F. S. Chapin, III, G. P. Kofinas, and C. Folke, editors. Principles of ecosystem stewardship: resiliencebased natural resource management in a changing world. Springer, New York, New York, USA. http://dx.doi.org/10.1007/978-0-387-73033-2 4

Kofinas, G. P., and F. S. Chapin, III. 2009. Sustaining livelihoods and human well-being during social-ecological change. Pages 55-75 in F. S. Chapin, III, G. P. Kofinas, and C. Folke, editors. Principles of ecosystem stewardship: resilience-based natural resource management in a changing world. Springer, New York, New York, USA. http://dx.doi.org/10.1007/978-0-387-73033-2_ 3

Larson, S., D. M. De Freitas, and C. C. Hicks. 2013a. Sense of place as a determinant of people's attitudes towards the environment: implications for natural resources management and planning in the Great Barrier Reef, Australia. Journal of Environmental Management 117:226-234. http://dx.doi.org/10.1016/ j.jenvman.2012.11.035

Larson, S., N. Stoeckl, B. Neil, and R. Welters. 2013b. Using residents perceptions of values associated with the Australian tropical rivers to identify policy and management priorities. Ecological Economics 94:9-18. http://dx.doi.org/10.1016/j. ecolecon.2013.07.005

Lockwood, M. 1999. Humans valuing nature: synthesising insights from philosophy, psychology and economics. Environmental Values 8:381-401. http://dx. doi.org/10.3197/096327199129341888
Lynam, T., H. Biggs, D. Du Toit, M. Etiennne, N. A. Jones, A. Leitch, R. Mathevet, P. Perez, S. Pollard, H. Ross, and S. StoneJovicich. 2012. Waypoints on a journey of discovery: mental models in human-environment interactions. Ecology and Society 17(3):23 http://dx.doi.org/10.5751/es-05118-170323

McDonald, D. H., R. Bark, A. MacRae, T. Kalivas, A. Grandgirard, and S. Strathearn. 2013. An interview methodology for exploring the values that community leaders assign to multiple-use landscapes. Ecology and Society 18(1):29. http://dx. doi.org/10.5751/es-05191-180129

Manning, R., W. Valliere, and W. Minteer. 1999. Values, ethics, and attitudes toward national forest management: an empirical study. Society and Natural Resources 12:421-436. http://dx.doi. org/10.1080/089419299279515

Mathevet, R., M. Etienne, T. Lynam, and C. Calvet. 2011. Water management in the Camargue Biosphere Reserve: insights from comparative mental models analysis. Ecology and Society 16 (1):43. online] URL: http://www.ecologyandsociety.org/vol16/ iss $1 / \operatorname{art} 43 /$

McIntosh, R. J. 2000. Social memory in Mande. Pages 141-180 in R. J. McIntosh, J. A. Tainter, and S. K. McIntosh, editors. The way the wind blows: climate, history, and human action. Columbia University Press, New York, New York, USA.

McIntyre, N., J. Moore, and M. Yuan. 2008. A place-based, values-centred approach to managing recreation on Canadian Crown Lands. Society and Natural Resources 21:657-670.

O'Brien, E. A. 2003. Human values and their importance to the development of forestry policy in Britain: a literature review. Forestry 76:3-17. http://dx.doi.org/10.1093/forestry/76.1.3

O’Neill, J., A. Holland, and A. Light. 2008. Environmental values. Routledge, Oxon, UK.

Olsson, P., C. Folke, and F. Berkes. 2004. Adaptive comanagement for building resilience in social-ecological systems. Environmental Management 34:75-90. http://dx.doi.org/10.1007/s00267-003-0101-7

Olsson, P., L. H. Gunderson, S. R. Carpenter, P. Ryan, L. Lebel, C. Folke, and C. S. Holling. 2006. Shooting the rapids: navigating transitions to adaptive governance of social-ecological systems. Ecology and Society 11(1):18. [online] URL: http://www. ecologyandsociety.org/vol11/iss1/art18/

Raymond, C. M., B. A. Bryan, D. H. McDonald, A. Cast, S. Strathearn, A. Grandgirard, and T. Kalivas. 2009. Mapping community values for natural capital and ecosystem services. Ecological Economics 68:1301-1315. http://dx.doi.org/10.1016/j. ecolecon.2008.12.006

Reser, J. P., and J. M. Bentrupperbäumer. 2005. What and where are environmental values? Assessing the impacts of current diversity of use of 'environmental' and 'world heritage' values. Journal of Environmental Psychology 25:125-146. http://dx.doi. org/10.1016/j.jenvp.2005.03.002

Robbins, J. 2012. Cultural values. Pages 115-132 in D. Fassin, editor. A companion to moral anthropology. John Wiley and Sons, New York, New York, USA. http://dx.doi.org/10.1002/9781118290620. $\underline{\operatorname{ch} 7}$ 
Rokeach, M. 1968. Beliefs, attitudes and values: a theory of organization and change. Jossey-Bass, San Francisco, California, USA.

Rokeach, M. 1973. The nature of human values. Free, New York, New York, USA.

Rolston, III, H. 1988. Human values and natural systems. Society and Natural Resources 1:269-283. http://dx.doi.org/10.1080/089$\underline{41928809380658}$

Rotarangi, S. J., and J. Stephenson. 2014. Resilience pivots: stability and identity in a social-ecological-cultural system. Ecology and Society 19(1):28. http://dx.doi.org/10.5751/ es-06262-190128

Rudel, T. K. 2011. Local actions, global effects? Understanding the circumstances in which locally beneficial environmental actions cumulate to have global effects. Ecology and Society 16 (2):19. [online] URL: http://www.ecologyandsociety.org/vol16/ iss $2 / \operatorname{art} 19 /$

Satterfield, T. 2001. In search of value literacy: suggestions for the elicitation of environmental values. Environmental Values 10:331-359. http://dx.doi.org/10.3197/096327101129340868

Scheffer, M., J. Bascompte, T. K. Bjordam, S. R. Carpenter, L. B. Clarke, C. Folke, P. Marquet, N. Mazzeo, M. Meerhoff, O. Sala, and F. R. Westley. 2015. Dual thinking for scientists. Ecology and Society 20(2):3. http://dx.doi.org/10.5751/es-07434-200203

Schroeder, H. W. 1996. Ecology and of the heart: understanding how people experience natural environments. Pages 13-27 in A. W. Ewert, editor. Natural resource management: the human dimension. Westview, Boulder, Colorado, USA.

Schroeder, H. W. 2013. Sensing value in place. Pages 73-87 in W. P. Stewart, D. R. Williams, and L. Kruger, editors. Place-based conservation: perspectives from the social sciences. Springer, Dordrecht, Germany. http://dx.doi.org/10.1007/978-94-007-5802-5_6

Schwartz, S. H. 1992. Universals in the content and structure of values: theoretical advances and empirical tests in 20 countries. Advances in Experimental Social Psychology 25:1-65. http://dx. doi.org/10.1016/S0065-2601(08)60281-6

Schwartz, S. H. 1994. Are there universal aspects of in the structure and contents of human values. Journal of Social Sciences 50:19-45. http://dx.doi.org/10.1111/j.1540-4560.1994.tb01196.x

Schwartz, S. H. 1996. Value priorities and behavior: applying a theory of integrated value systems. Pages 1-24 in C. Seligman, J. M. Olson, and M. P. Zanna, editors. The psychology of values: the Ontario symposium. Erlbaum, Hillsdale, New Jersey, USA.

Schwartz, S. 2010. Values: individual and cultural. Pages 463-493 in F. J. R. van de Vijver, A. Chasiotis, and S. M. Breugelmans, editors. Fundamental questions in cross-cultural psychology. Cambridge University Press, Cambridge, UK. http://dx.doi. org/10.1017/cbo9780511974090.019

Seymour, E., A. Curtis, D. Pannell, C. Allan, and A. Roberts. 2012. Understanding the role of assigned values in natural resource management. Australasian Journal of Environmental Management 17:142-153. http://dx.doi.org/10.1080/14486563.20$\underline{10.9725261}$
Seymour, E., A. Curtis, D. J. Pannell, A. Roberts, and C. Allan. 2011. Same river, different values and why it matters. Ecological Management and Restoration 12:207-213. http://dx.doi. org/10.1111/j.1442-8903.2011.00605.X

Steel, B. S., P. List, and B. Shindler. 1994. Conflicting values about federal forests: a comparison of national and Oregon publics. Society and Natural Resources 7:137-153. http://dx.doi. org/10.1080/08941929409380852

Steg, L., L. Dreijerink, and W. Abrahamse. 2005. Factors influencing the acceptability of energy policies: a test of VBN theory. Journal of Environmental Pyschology 25:415-425. http:// dx.doi.org/10.1016/j.jenvp.2005.08.003

Stephenson, J. 2008. The cultural values model: an integrated approach to values in landscapes. Landscape and Urban Planning 84:127-139. http://dx.doi.org/10.1016/j.landurbplan.2007.07.003

Stern, P. C., and T. Dietz. 1994. The value basis of environmental concern. Journal of Social Issues 50:65-84. http://dx.doi. org/10.1111/j.1540-4560.1994.tb02420.x

Stern, P. C., T. Dietz, and G. A. Guagnano. 1998. A brief inventory of values. Educational and Psychological Measurement 58:984-1001. http://dx.doi.org/10.1177/0013164498058006008

Strang, V. 2005. Common senses: water, sensory experience and the generation of meaning. Journal of Material Culture 10:92-120. http://dx.doi.org/10.1177/1359183505050096

Swedeen, P. 2006. Post-normal science in practice: a Q study of the potential for sustainable forestry in Washington State, USA. Ecological Economics 57:190-208. http://dx.doi.org/10.1016/j. ecolecon.2005.04.003

Thacher, D., and D. Rein. 2004. Managing value conflict. Governance 17:457-486. http://dx.doi.org/10.1111/j.0952-1895.2004.00254. $\underline{\mathrm{x}}$

Trainor, S. F. 2006. Realms of values: conflicting natural resource values and incommensurability. Environmental Values 15:3-29. http://dx.doi.org/10.3197/096327106776678951

Turner, N. J., and F. Berkes. 2006. Coming to understanding: developing conservation through incremental learning in the Pacific Northwest. Human Ecology 34:495-513. http://dx.doi. org/10.1007/s10745-006-9042-0

Vaske, J. J., and M. P. Donnelly. 1999. A value-attitude-behavior model predicting wildland preservation voting intentions. Society and Natural Resources 12:523-537. http://dx.doi. org/10.1080/089419299279425

Vaske, J. J., M. P. Donnelly, D. R. Williams, and S. Jonker. 2001. Demographic influences on environmental value orientations and normative beliefs about national forest management. Society and Natural Resources 14:761-776. http://dx.doi.org/10.1080/089419201753210585

Vugteveen, P., H. J. R. Lenders, J. L. A. Devilee, R. S. E. W. Leuven, R. J. H. M. van der Veeren, M. A. Wiering, and A. J. Hendricks. 2010. Stakeholder value orientations in water management. Society and Natural Resources 23:805-821. http:// dx.doi.org/10.1080/08941920903496952 
Walker, B., L. H. Gunderson, A. P. Kinzig, C. Folke, S. R. Carpenter, and L. Schultz. 2006. A handful of heuristics and some propositions for understanding resilience in social-ecological systems. Ecology and Society 11(1):13. [online] URL: http://www. ecologyandsociety.org/vol11/iss1/art13/

Walker, B. H., S. R. Carpenter, J. Rockström, A.-S. Crépin, and G. D. Peterson. 2012. Drivers, "slow" variables, "fast" variables, shocks, and resilience. Ecology and Society 17(3):30. http://dx.doi. org/10.5751/es-05063-170330 